\title{
Forebygging av selvmord utført ved forgiftning med pesticider
}

\author{
Ved José M Bertolote og Alexandra Fleischmann
}

\begin{abstract}
Selvpåført forgiftning med pesticider (plantevernmidler) er et stort folkehelseproblem i mange jordbrukssamfunn i land med lave og midlere inntekter rundt om i verden. Pesticider er lett tilgjengelige i de fleste husholdninger på landsbygda, og det er vanlig å bruke dem til selvpåførte forgiftninger. På grunn av den svært høye dødeligheten som skyldes at pesticidene er sterkt giftige, ender mange av disse impulsive handlingene med døden (Mishara, 2007; Phillips et al., 2002). I og med at inntak av pesticider er kjent for å være en av de hyppigst brukte selvmordsmetodene på verdensbasis (Bertolote et al., 2006a; Eddleston et al., 2006; Gunnell e Eddleston, 2003), kan strategier som tar sikte på å redusere selvpåført forgiftning med pesticider, ha stor innvirkning på den globale selvmordsraten (Bertolote et al., 2006b).
\end{abstract}

\section{Rater}

Basert på data fra Sri Lanka anslo Jeyaratnam allerede i 1985 at anslagsvis 220000 årlige dødsfall i den tredje verden skyldes pesticidforgiftning (J eyaratnam, 1985). Bortimot 20 år senere er det anslått at det hvert år forekommer omkring 300000 selvmord forårsaket av overlagt inntak av pesticider rundt om i verden, og at dette særlig finner sted på landsbygda i Asia (Gunnell \& Eddleston, 2003). Dette estimatet er basert på forskningsresultater som tyder på at inntak av pesticider står for over 60 prosent av alle selvmord i mange landdistrikter i Kina og Sørøst-Asia.

Til det siste estimatet over dødsfall som skyldes forgiftning med pesticider, ble det for første gang benyttet data fra alle de regionene Verdens helseorganisasjon (WH O) dekker. Som et konservativt anslag er det rapportert om

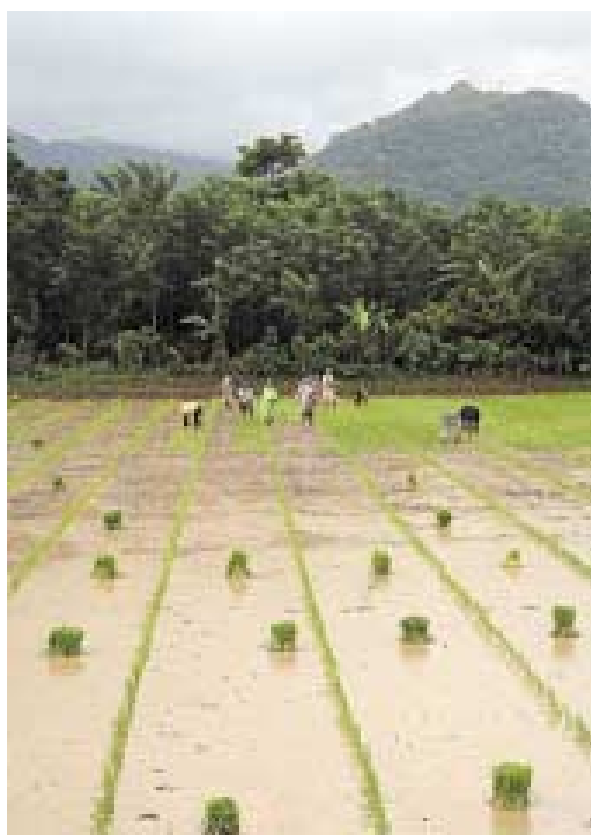

258234 årlige pesticidselvmord verden over, med mulige variasjoner innenfor området 234000 til 326000 (Gunnell et al., 2007). Dette representerer omkring en tredel av alle selvmord på verdensbasis. I og med at det ble stilt spørsmål ved hvor pålitelig selvmordsstatistikken for India var, og fordi nyere studier fra den indiske landsbygda ble tatt med i betraktningen, hevdet forfatterne at estimert antall selvmord som skyldtes pesticider, faktisk kunne være så høyt som 371594.

I den samme artikkelen la Gunnell og hans kolleger (2007) fram en systematisk gjennomgang av studier av dødelig selvpåført forgiftning med pesticider rundt om $\mathrm{i}$ verden. Blant disse var følgende: I Kina og M alaysia, begge land tilhørende WHOs vestlige stillehavsregion, viste studier at henholdsvis $62 \%$ og over $90 \%$ av alle selvmord skyldtes selvpåført forgiftning med pesticider. I WHO s sørøstasiatiske region påviste en studie fra Sri Lanka at $70 \%$ prosent av alle selvmord ble gjennomført ved inntak av pesticider. Data fra land i M ellom-Amerika og Sør-Amerika i WH O s såkalte Amerikaregion vitnet også om den rollen pesticider spiller i forbindelse med selvmord, for eksempel i Trinidad (68\%) og Suriname ( $50 \%$ ). Dette kan kompletteres med informasjon fra WHO M ortality Database, der det går fram at sel vpåført forgiftning med pesticider var benyttet i forbindelse med $86 \%$ av selvmord i EI Salvador. I WHOs afrikanske region viste en rapport at Malawi hadde den høyeste andelen av pesticider knyttet til selvmord ( $79 \%$ ). I Pakistan, et land som tilhører WH Os $ø$ øtlige middelhavsregion, kunne én studie rapportere om $39 \%$ pesticidselvmord. I WHO s europeiske region ble det rapportert om selvmord ved inntak av pesticider i enkelte områder, som Almeria-provinsen i Spania ( $22 \%$ ) og den sørvestlige delen av H ellas (19\%).

\section{En global handlingsplan}

Når man tenker på at selvpåført forgiftning med pesticider er et alvorlig offentlig helseproblem og man samtidig tar hensyn til den forholdsvis begrensete oppmerksomheten dette hittil har vært gjenstand for sammenlignet med det omfanget det forekommer i (både når det gjelder dødelighet og sykelighet), har WH O lansert et tverrsektorielt folkehelseinitiativ med tittelen "The I mpact of Pesticides on $\mathrm{H}$ ealth: Preventing Intentional and Unintentional Deaths from Pesticide Poisoning" som et ledd i WH O s verdensomspennende initiativ for selvmordsforebygging (SU PRE). I og med at de har felles interesser og anliggender, har Verdens helseorganisasjons avdeling for psykisk helse og stoffmisbruk, avdeling for vold, skadeforebygging og uførhet og programmet til fremme av kjemisk sikkerhet gått sammen, i tillegg til at de samarbeider med andre partnere, både innenfor og utenfor organisasjonen, om å skape blest om dette viktige initiativet.

Det overordnede målet er å redusere dødelighet og sykelighet knyttet til pesticidforgiftning. Mer spesifikt er målsettingene som følger:

i) gjennomgå og anbefale bedre reguleringstiltak for bruk av pesticider,

ii) iverksette en bærekraftig epidemiologisk overvåking og oppfølging av pesticidforgiftning i kliniske sammenhenger og lokal samfunn, 
iii) forbedre den somatiske medisinske og psykiatriske behandlingen til personer med pesticidforgiftning i helseforetak på forskjellige nivåer,

iv) sørge for opplæring i trygg omgang med pesticider, samt diagnostikk og behandling av pesticidforgiftning i forskjellige sektorer og på ulike nivåer, samt

v) utvikle eller styrke offentlige tiltak som minimaliserer risikoen for overlagt og uoverlagt pesticidforgiftning.

Når ikke-dødelig og dødelig selvpåført forgiftning med pesticider spiller en så viktig rolle i forbindelse med suicidal atferd, er det helt avgjørende at relevante forebyggende tiltak har sin forankring i nasjonale tiltak for selvmordsforebygging. Sannheten er dessverre at slike tiltak inntil videre stort sett er ikke-eksisterende i land med lav eller middels per capita-inntekt. Av den grunn har WHO startet et samarbeid med myndigheter rundt om i hele verden for å øke oppmerksomheten om betydningen og omfanget av suicidal atferd, og for å sørge for assistanse når det gjelder å utvikle og gjennomføre nasjonale strategier for selvmordsforebygging.

Det er helt avgjørende at myndighetene ratifiserer, iverksetter og håndhever $\mathrm{H}$ azardous Chemicals and Wastes Conventions, det vil si Basel-, Rotterdam- og Stockholm-konvensjonene, som omfatter nøkkelelementer i administreringen av farlige kjemiske stoffer (www.basel.int; www.pic.int; www.pops.int; siste gang gjort tilgjengelig 10. januar 2007). M ens det første avgjørende skrittet er tatt i mange land, byr iverksettingen på store utfordringer som følge av spesielle barrierer, som manglende økonomiske midler, manglende ekspertise, menneskelige ressurser og opplæring, behovet for avanserte teknologiske løsninger og utstyr, de begrensede databasesystemene som er tilgjengelige, samt manglende oppmerksomhet fra det offentliges side. Kon radsen og hans kolleger
(2005) understreket behovet for at disse konvensjonene ikke bare foreslår iverksetting av tiltak som utfasing av de giftigste kjemikaliene, fremming av alternative skadedyrbekjempende tiltak eller tryggere oppbevaring, men også at de helt eksplisitt inkluderer selvpåførte forgiftninger i sine risikovurderinger og direkte tar opp temaet selvpåførte skader.

Når det gjelder den tredje målsettingen (iii) i det WHO-initiativet som er nevnt ovenfor, innkalte WHO til et ekspertmøte i desember 2007 for å finne frem til effektiv behandling av akutt pesticidforgiftning (både tilfeldig og overlagt) på forskjellige nivåer innenfor helsevesenet, for eksempel primærhelsetjenesten, regionale sykehus og spesialiserte enheter. Selv om det hadde foreligget diverse omfattende eller begrensede retningslinjer for denne behandlingen, hvorav noen skyldtesforskjellige programmer innenfor WH O, er tiden nå inne for å foreta en dyptgripende gjennomgang av disse tidligere initiativene og omgjøre dem til klare kliniske retningslinjer som kunne brukes av helsepersonell og angi nøyaktig hvor de skulle benyttes innenfor helsevesenet.

Så snart slike retningslinjer er blitt tilgjengelige, kan det - som indikert under målsetting (iv) ovenfor - iverksettes opplæring på de forskjellige nivåene. På grunn av mangelen på informasjon er det dessuten et annet hovedmål (ii) å fă i gang en bærekraftig epidemiologisk overvåking og oppfølging av pesticidforgiftning $i$ kliniske omgivelser og lokalsamfunn.

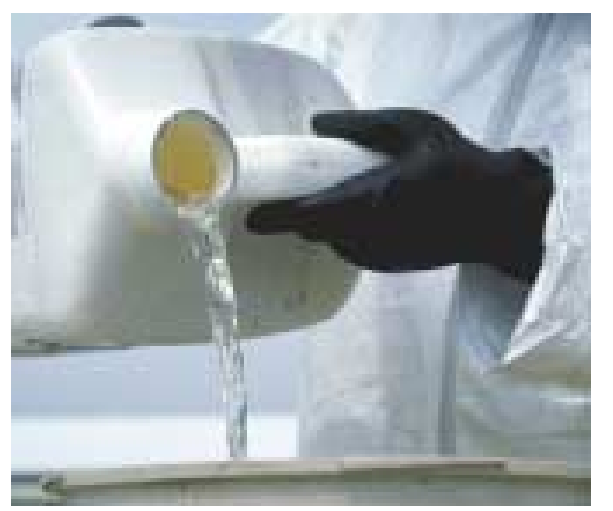

Samarbeid med Den internasjonale foreningen for selvmordsforebygging (IASP)

$N$ år det gjelder den femte målsettingen (v), har WHO og IASP, en internasjonal ikke-statlig organisasjon med offisiell tilknytning til WHO, blitt enige om et prosjektsamarbeid for å gjennomføre felles aktiviteter i tilknytning til "Best practices on community action for safer access to pesticides" (De beste samfunnsmessige tiltak for tryggere omgang med pesticider). Dette samarbeidet startet med et ekspertmøte i 2006, der målet var å kartlegge det aktuelle kunnskapsnivået når det gjaldt effektive og akseptable inngrep fra samfunnets side, som har et betydelig potensial til å forebygge sel vskading i form av pesticidforgiftning. Den grunnleggende informasjonen og de anbefalingene som ble resultatet av dette møtet, ble sammenfattet i en publikasjon med tittelen: "Safer Access to Pesticides: Community Interventions" (Verdens helseorganisasjon, 2006).

Blant de samfunnsmessige inngrepene søkelyset ble rettet mot, var slike som gikk på tryggere oppbevaring, utdanning og psykososiale intervensjoner, som de følgende:

- Låste skap for oppbevaring av pesticider i gårdshusholdninger.

- Sentralisert offentlig oppbevaring av pesticider.

- O pplæring av pesticidbrukere i de helsefarene som knytter seg til bruk av pesticider og om trygg bruk, oppbevaring og avhending av pesticider.

- O pplæring av ressurspersoner / opinionsledere for å sikre at de sitter med den mest oppdaterte informasjonen om forebygging, identifisering og akutt håndtering av helseproblemer som skyldes bruk av pesticider.

- O pplæring av forhandlere for å gi pesticidbrukere innblikk i helsefarer og egnet bruk, oppbevaring og avhending av pesticider og for å holde kontroll med i hvilken utstrekning de overholder bestemmelsene. 
- Samarbeid med lokale massemedier for å støtte opp om opplegg rettet mot å minske omfanget av pesticidrelaterte selvmord og å redusere uheldig mediefokusering på selvmord som kan føre til at andre lar seg inspirere til å gjøre det samme.

- O pplæring av skolebarn i trygg bruk, oppbevaring og avhending av pesticider, samt psykososiale inter vensjoner for å øke samfunn sbaserte tiltak med hensyn til administrering av pesticider.

Følgende anbefalinger ble formulert:

- Landene gjennomgår listen over godkjente produkter til bruk i jordbruket og fjerner dem som ikke oppfyller Basel-, Rotterdamog Stockholm-konvensjonene.

- Landene ser nærmere på virkningen av dødelig og ikke-dødelig suicidal atferd i den nasjonale dødelighetsprofilen og den nasjonale skadeprofilen, samt den spesifikke rollen pesticider spiller i den forbindelse.

- I land eller regioner der overlagt eller uoverlagt pesticidforgiftning representerer et folkehelseproblem, bør de involverte partene (myndigheter, regioner, lokalsamfunn, ikke-statlige organisasjoner osv.) iverksette en rekke spesifikke tiltak for å vurdere gjennomførbarheten og effektiviteten av de foreslåtte samfunnsinngrepene og tilpasse dem lokale forhold, iverksette dem og evaluere utfallene og hvor bærekraftige de er.
I samarbeid med IASP ble det så i desember 2007 arrangert et møte der temaet var "Feasibility Demonstration Projects on Community Inter ventions for Safer Access to Pesticides" (Prosjekter for å påvise gjennomførbarhet av samfunnsmessige intervensjoner for å oppnå tryggere omgang med pesticider). H ensikten med møtet var å velge ut inter vensjoner blant dem som tidligere var blitt identifisert, og sette opp protokoller med henblikk på å iverksette prosjekter for å finne ut hvor gjennomførbare disse tiltakene var. Det man for ventet seg av møtet, var å få satt opp protokoller som påviste gjennomførbarheten av tiltak på lokalplan for å oppnå tryggere adgang til pesticider, videre å finne frem til steder der disses prosjektene kunne iverksettes og personer som kunne lede prosjektene. De foreslåtte tiltakene omfattet sentralisert offentlig oppbevaring av pesticider, kooperative innkjøp og felles distribusjon av pesticider på landsbyplan, trygg oppbevaring av pesticider, samt en samfunnsomfattende innsats for å spre kunnskap med henblikk på å øke oppmerksomheten rundt de helsefarene som knytter seg til bruk av pesticider.

\section{Konklusjon}

I hvilken grad man skal lykkes med det tverrsektorielle folkehelseinitiativet for å senke den dødeligheten og sykeligheten som knytter seg til pesticidforgiftning, vil avhenge av bred støtte fra både offentlig og privat sektor, noe som omfatter relevante ikke-statlige organisasjoner og underbruk av FN.

\section{Referanser}

Bertolote JM, Fleischmann A, Butchart A, Besbelli N. Suicide, suicide attempts and pesticides: a major hidden public health problem. Bulletin of the World Health O rganization 2006a; 84, 260-261.

Bertolote JM, Fleischmann A, Eddleston M, Gunnell, D. Deaths from pesticide poisoning: a global response. British journal of Psychiatry 2006b; 189, 201-203.

Eddleston M, Buckley NA, Gunnell D, Dawson $A H$, Konradsen $F$. Identification of strategies to prevent death after pesticide self-poisoning using a $\mathrm{H}$ addon matrix. Injury Prevention 2006; 12, 333-337.
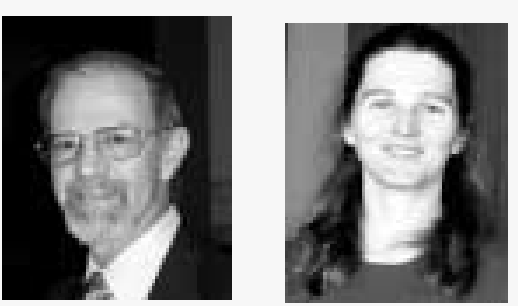

José Manoel Bertolote er koordinator for Team for Management of $M$ ental and Brain Disorders, Department of Mental H ealth and Substance Abuse, Verdens hel seorganisasjon, Genève, Sveits. Et av hans ansvarsområder er SUPRE, Verdens helseorganisasjons globale initiativ for selvmordsforebygging. I tillegg er Bertolote professor ved Alderspsykiatrisk avdeling ved Universitetet i Lausanne i Sveits.

Alexandra Fleischmann arbeider for Team for Management of Mental and Brain Disorders, Department of Mental Health and Substance Abuse, Verdens helseorganisasjon, Genève, Sveits. Hennes hovedoppgaver knytter seg til Verdens helseorganisasjons gl obale initiativ for selvmordsforebygging.

Forfatterne arbeider for Verdens helseorganisasjon, men de synspunktene som kommer til uttrykk i denne artikkelen, står ene og alene for deres regning, og de er ikke nødvendigvis representative for Verdens helseorganisasjons beslutninger, policy eller synspunkter.

(Artikkelen er oversatt av Dag Biseth)

Gunnell D, Eddleston M, Phillips MR, Konradsen $F$. The global distribution of fatal pesticide self-poisoning: systematic review. BMC Public Health 2007; 7, 357-395.

Gunnell D, Eddleston M. Suicide by intentional ingestion of pesticides: a continuing tragedy in developing countries. International Journal of Epidemiology 2003; 32, 902-909.

Jeyaratnam J. H ealth problems of pesticide usage in the third world. British Journal of Industrial Medicine 1985; 42, 505-506.

Konradsen F, van der Hoek W, Gunnell D, Eddleston, $M$. Missing deaths from pesticide self-poisoning in the IFCS Forum IV. Bulletin of the World Health Organization 2005; 83 , 157-158.

Mishara BL. Prevention of deaths from intentional pesticide poisoning. Crisis 2007; 28 (Suppl.1), 10-20.

Phillips MR, Yang G, Zhang Y, Wang L, Ji H, Zhou M. Risk factors for suicide in China: a national case-control psychological autopsy study. L ancet 2002; 360, 1728-1736.

World Health Organization. Safer access to pesticides: Community interventions. Geneva: WH O, 2006. 